\title{
Study for a new definition of the southern side of Prato della Valle in Padua, Italy
}

\author{
Enrico Pietrogrande, Alessandro Dalla Caneva \\ Department of Civil, Environmental, Architectural Engineering. University of Padua. Italy \\ E-mail: juanmiguelmunoz.corbalan@ub.edu
}

\begin{abstract}
Research The boundary wall of the Santa Maria della Misericordia convent continuously delimited the southern limit of the Prato della Valle space in the southern part of Padua's historical centre. Its presence was one of the elements that more than two century ago inspired the enlightened proposal by Andrea Memmo, the Superintendent of the Republic of Venice, and Domenico Cerato, a design professor at the University of Padua. Subsequently the straight and continuous limit was replaced by the discontinuous architecture of the Foro Boario entrance, built in 1913 according to a design by Alessandro Peretti; this weakened the overall solution based on an elliptical shape and the communicative power of the nearby basilica of Santa Giustina. The examination here presented dwells on these limits, simulating the virtual introduction of architectures with a continuous front to the southern edge of the Prato della Valle. One example is the Nelson-Atkins Museum of Art built in Kansas City between 1930 and 1933, based on a design by the brothers Thomas and William Wight, and expanded in 1999 by Steven Hall. The study generally confirmed that the compactness of the building's front newly provides strength to the late 18th century Memmo's creative intuition, which gave a sense of unity to the general emptiness thanks to the certainty of its borders, and gives again the Basilica of Santa Giustina its monumental size. This paper investigates the composition of heterogeneous fragments, excerpts from the inventory of collective memory, and the resulting unpredictable architecture in an urban context.
\end{abstract}

Keywords: Imaginary City, Possible City, Memories, Urban Setting, Prato della Valle, Architecture and Enlightenment.

\section{Introduction}

This is a study set in Padua, a city in Northeast Italy. For four hundred years, Padua was part of the Serenissima Republic of Venice, until the end of 18th century. The subject addressed implies the reminder of the very crucial period when Padua on the one hand was reached by the ideas of Enlightenment, on the other was briefly occupied by Napoleon's Army, which closed many churches, monasteries and convents. Wide parts of the urban tissue became abandoned, without users and functions.

In particular, the place here considered is a large area of open space in the southern part of the city called Prato della Valle (Figures 1,2). A general method for initial verification of the potential offered by the planning project was applied to this specific place for finding out how to tackle a theme of great delicacy in the specific case of Prato della Valle. Premising all that follows is the conviction that the building currently in place on the southern side of Prato della Valle is largely inappropriate compared to the quality of the synthesis built here in the Age of Enlightenment at the end of the 18th century.

So a method based on principles of potential interchangeability of context and the monument was applied to this particular 
case. It involves accepting the transfer of notable works of architecture outside the original environment and verifying the role and outcome in a different location. This is the reason why this contribution is considered by the authors relevant to the conference's theme of "City and territory in the globalization era". Globalization is an opportunity to evaluate the opportunities for enhancement of the context in question in presence of monuments whose relationship with the place is unconvincing.

A similar procedure that tests the possibility of enhancement of the context and the monument was experimented by the greatest architect of romantic classicism, Karl Friedrich Schinkel, and can be seen in one of his best known designs called Large composition, how Milan Cathedral should be situated (1810). So the monument of the Lombard city is represented on a hill that overlooks a large city on the coast, perhaps Trieste, in order to test a new version of the relationship, here between architecture and nature. It is one of the most well-known anticipated explorations carried out in the past in a planning method facilitating upstream project verification aimed at the evaluation on the one hand of the impact of a new architecture on the environment, and on the other hand, of the opportunity to enhance a given place.

Karl Friedrich Schinkel assembled architectures and built places in several other designs, as Piazza aperta sul mare con motivi veneziani (Square on the sea with Venetian themes) and Disegno di città immaginaria (Design of an imaginary city) both painted at the beginning of the 19-th century. Luciano Semerani has observed that his love of ancient Greece brought Schinkel to favour the topological relationship between the objects, "which he placed to constitute a minute faceto-face dialogue with great correlations with the urban structure". Observing the views of the buildings recomposed by Schinkel in the reciprocal dialogue and in relationship with the context, it is notable that Semerani writes "Schinkel's interest is almost never in individual monuments or architectural ruins but he usually shows them inserted in generous sweeping landscapes (...). Schinkel interprets the landscape and composes images". It is a matter of "working by memory, by citations, by transposing objects outside their normal context" in a "real and true invention of context, an attitude that also lives in 'visionary' architects". (Semerani 1982). It is not by coincidence that Schinkel was firstly a painter and a scenographer, and among the other important architects Hendrik Petrus Berlage trained as a painter before embarking on a career as an architect, and Le Corbusier painted on a daily basis.

Similarly, the interest that the famous Venetian painter Giovanni Antonio Canal, known as Canaletto (1697-1768), shows in some of his mid-18th century canvasses constitutes a point of reference for this methodological direction. Not only Palladio's Rialto Bridge project appears with a certain frequency in the views of Venice painted by Canaletto, but the artist represented in his painting Caprice with buildings by Palladio of 1756-59 the Palladio's Bridge with two other works designed by Palladio, Palazzo Chiericati and the Basilica, that are part of the city of Vicenza. The bridge, the Basilica, and Palazzo Chiericati are placed in the scene and commented on as if the artist wanted to present a view of an urban context effectively observed by him. In the chosen environment, Canaletto juxtaposes architectures from other places and epochs providing form to new spatial connections, thereby verifying unthoughtof opportunities to compose buildings and monuments that modify the space. Through the practice of constructing by using perspective, architectures put into play acquire a new relief that attributes power to both the context enriched with new value and to the individual projects in their renewed conversation and/or interaction with the context.

The architect Aldo Rossi is author of one of the most significant comments about this work of art. "What matters most in this frame is the theoretical construction, the hypotheses of a theory of architectural planning in which the elements are formally prefixed and defined but in which the meaning triggered at the end of the operation is the unexpected but authentic original meaning of the research" (Rossi, 1975). The architectural project in Canaletto's Rialto is compared with the place 
and inevitably interacts with it by proposing alternatives to the real city.

\section{The place of study. Prato della Valle as an} expression of the Enlightenment culture

The place of study, what the Rialto in Venice was for Canaletto and the hill of San Giusto overlooking Trieste was for Schinkel, in the case considered in this article is Prato della Valle in Padua and especially its southern side, where the wall delimiting the fields of the convent of Santa Maria della Misericordia rose (Toffanin, 1988). The old complex of the Benedictine convent particularly flourished in the mid-18th century, and the convent still existed in the years in which the Age of Enlightenment project for Prato della Valle was designed and developed and may be considered to have constituted an inspirational element. It was suppressed under Napoleonic laws in 1808. The church and church tower were demolished and part of the convent was transformed into housing. Then later all of this was demolished once and for all so that the Foro Boario and the Stadio Appiani could be built in the 1930s.

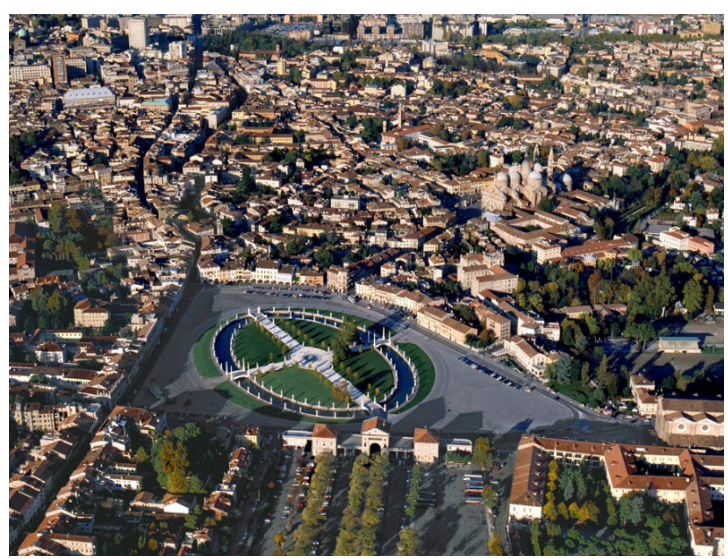

Figure 1. Aerial view of Prato della Valle, Padua. Current state.

The long wall of the convent's fields therefore constituted the southern limit of the Prato della Valle wide space when Andrea Memmo (1729-1793), from 1775 extraordinary Superintendent of the Serenissima Republic of Venice, instigated the initiative to redevelop the marshy area of Prato della Valle and transform it into a meeting and business centre for the whole city. Memmo was assisted by the Abbott and architect Domenico Cerato (17151792). The project, that was in line with similar breath-taking ideas realized in European capitals, was approved by the Venetian Senate on the 3 August 1775 (Zaggia, 2016) and was subsequently several times subject to rethinking and variation.

The layout is based on the design of an elliptical island at the centre, known as "Isola Memmia" in honour of its creator, Andrea Memmo. The island was created through the relocation of a great deal of earth, about ten thousand cartloads (Radicchio, 1786), to reclaim the marshy land. It was surrounded by an artificial canal, crossed by four bridges on the axes of the ellipse. The shores were lined with a double row of statues representing illustrious Paduans, including adopted figures and Padua natives. The water was supplied by the Alicorno canal, largely covered today. According to the original version, the island was to accommodate a wooden structure containing fifty-four shops, designed to follow the elliptical form of the canal. However, this original concept was later limited only to the south part of the ellipse, before being abandoned altogether.

Memmo lived in the 15th century palace situated at the northern entrance to Prato della Valle and could thus oversee the work being carried out. He planned for the area's commercial relaunch to coincide with an overhaul of its sanitation. Prato della Valle was to be transformed into an appropriate setting for the local seasonal fairs and events that were traditionally held there, whilst also being suitable for providing refreshment for the population.

Numerous depictions testify to the presence of the wall that was solidly capable of responding to the elastic nature of the island. All of the views show the continuous masonry of the convent delimiting the southern side of the wide open space. The mid-18th century painting by Canaletto shows the Prato della Valle space before the transformation during the Age of Enlightenment, with all of the southern side in view and the green grass of the land in the convent appearing above the 
masonry of the enclosing. Furthermore, as shown in the painting of Lorenzo Sacchetti (1759-1835) of 1775 or 1776 and in the views of Daniele Danieletti, the straight wall that delimits the property of the convent does not seem to have been modified during the construction of Memmo's project. Of particular relevance to our purposes is the view drawn by Giuseppe Subleyras (1781-1794) and engraved by Francesco Piranesi (1758-1810) showing a continuous three-storey building that contains the spaces used to transact business, closing

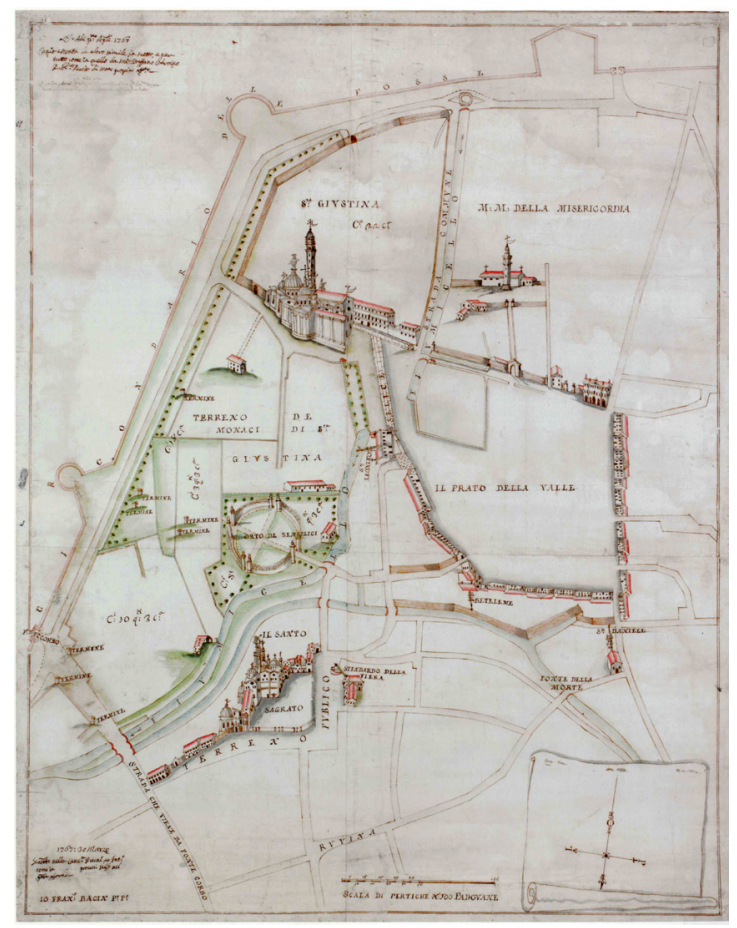

Figure 2. Prato della Valle. Drawing by Stefano Codroipo, copy of the original by Giovan Francesco Bacin, 1767. with a straight development which conceals the church of the Misericordia the southern side of Prato della Valle. In 1786 Subleyras depicted a building whose uninterrupted length covers the distance that separates the monastery of Santa Giustina to the east and Palazzo Verson to the west (Figure 3), implying the "movement of the business functions outside the island" (Donvito 2016). According to this proposal, the view in all directions from the island would have remained free and this would only have been used as a public garden.

\section{The Foro Boario architecture}

The current conformation of the southern tract of Prato della Valle arose in the first part of the Twentieth Century and is still composed of the entrance building to the Foro Boario (Figure 4), which is the livestock market that has been held in the middle of the square's large open space since 1775. As Renzo Fontana writes, "after having discarded various proposals and projects to move the market elsewhere, in 1913 the local council bought the area, property of the Padri Armeni, and the project to build the Foro Boario was entrusted to the engineer Alessandro Peretti. Construction work began in 1914" (Fontana, 2000). The area bordering on the southern side of the Prato della Valle was therefore used for this specific function that was maintained until a new Foro Boario was built in Corso Australia outside the historic centre of Padua after the Second World War.

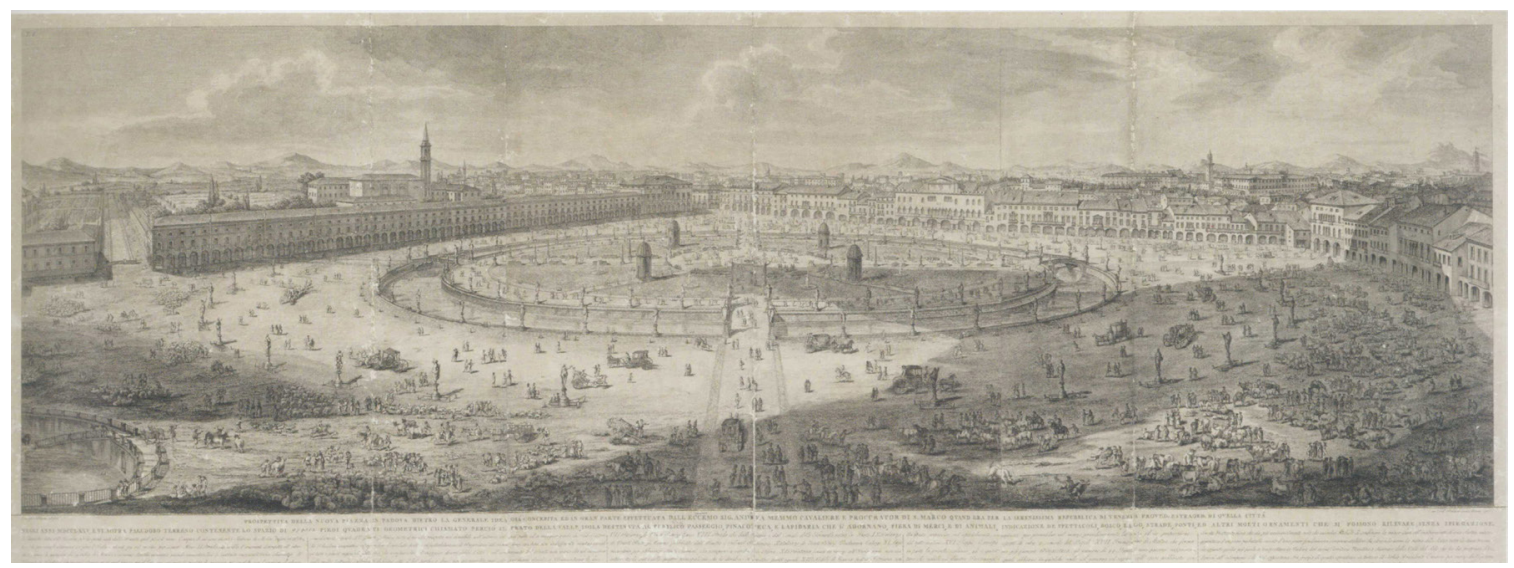

Figure 3. View of Prato della Valle with an imagined continuous three-storey building on the south side. Drawing by Giuseppe Subleyras engraved by Francesco Piranesi, 1776. 
The style adopted by the new architecture does not seem to be important here but is still well described by Fontana: "The language is impressed on an eclectic taste with the prevalence of motifs from the classicalrenaissance list (columns, pediment, metope and triglyph frieze, gabled windows, with ashlar work on the ground floor)". Above all, Peretti's Foro Boario is characterised by the lack of continuity of the long façade, composed of alternating detached volumes, with large gaps and empty spaces between these volumes, the opposite of the full straight façade that historically delimited this space. In fact, Nicla Bedin says that the façade "is composed of three blocks overlooking Prato della Valle with two symmetrical lateral bodies, joined together by terraces and open galleries" (Bedin, 2004). The façade of the entrance into the large area of the new livestock market, which will soon be completed with ceilings and stalls, "is born as a multifunctional construction, 135 metres long, in which post and telegraph offices, banks, and veterinary centres will be hosted."

The proposal of verifying the result that would have been obtained using an architectural solution closer to the compactness of the historic limit of this space is specifically motivated by the fragmentary nature of the solution built between 1913 and 1914, with a greater attention being paid to the functional and aesthetic requirements of the Foro Boario and less to provide a general coherence of the buildings around the elliptical square. On the other hand, this appearance had already been noted at the time. In fact, Mario Universo writes "here we have a project that is (...) another drop-scene of stone, so magnificent outside but empty inside, 'a luxury job, useless and unproductive' as the chairman of the Chamber of Commerce R. Mion defined it in 1914" (Universo, 1986). It should be also added that the bibliography does not contain particularly positive opinions regarding the Foro Boario.

\section{Simulations}

In order to carry out the initial evaluation of how Prato della Valle would present itself if its southern side were still composed as it was in the past, that is, deleting the perforated incoherent façade of the Foro Boario which deeply weakened the strength of the revolutionary design by Memmo and Cerato, two different architectures have been virtually placed in the site. These architectures are two masterpieces with compact and continuous façades, located to redefine the boundary that historically defined the marshy public space and, after the end of the 18th century, the pressure of the ellipse that gave it form.

The first hypothesis involves a construction by Schinkel standing on the south boundary of the elliptical square, the Altes Museum (Figure 5) which overlooks in Berlin another garden,

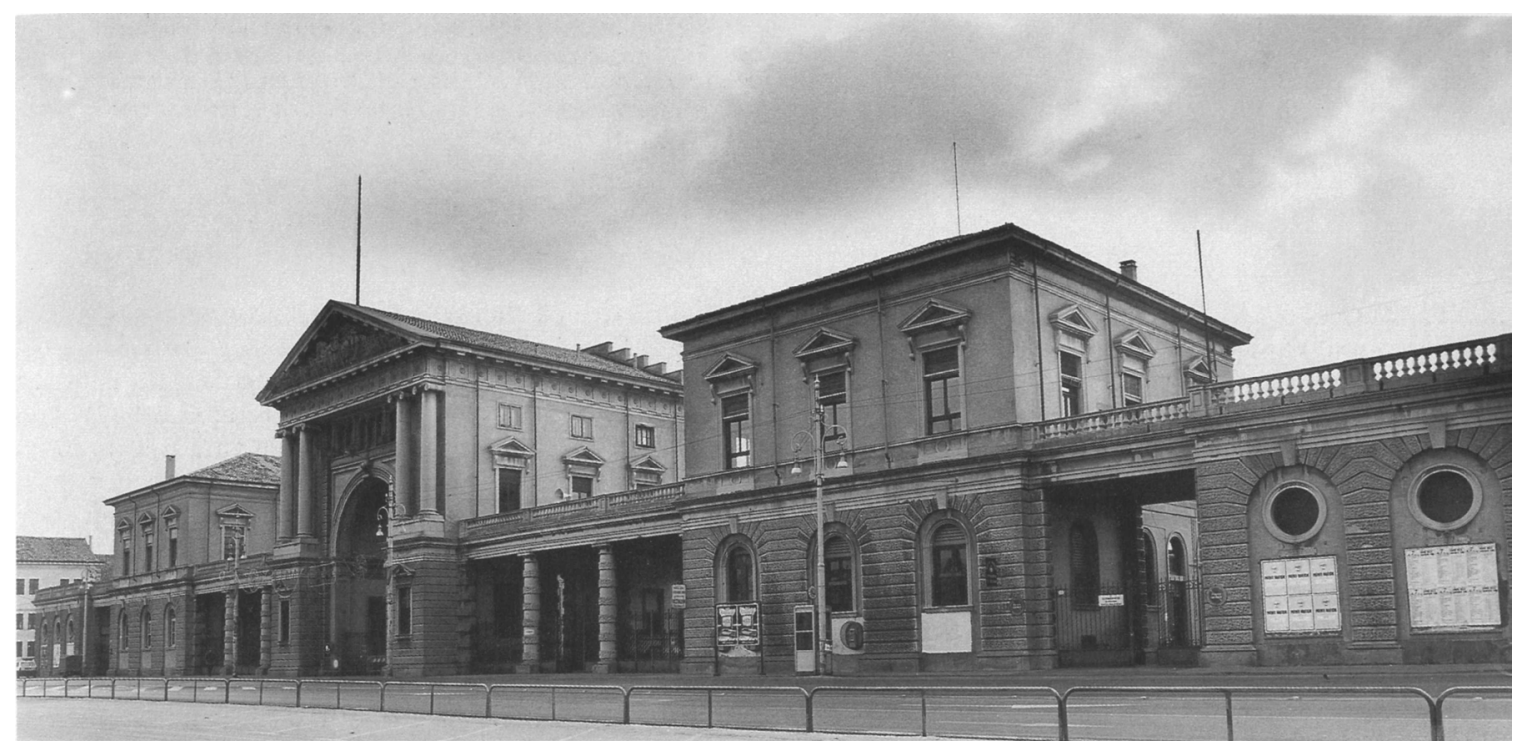

Figure 4. Alessandro Peretti, façade of the Foro Boario, 1913. 
the Lustgarten. The Altes Museum was planned and built between 1823 and 1830. The building structure brings together for a very unified outcome its composite elements, characterised by its regular design offering immediate readability, and its reciprocal juxtaposition. On the façade facing the Lustgarten, or the Prato della Valle in this virtual hypothesis, the eighteen ionic columns between the two corner pillars, designed without pediment, are placed at the front of a shallow portico, blurring the border between the external open space and the interior area. Behind the portico are the stairs that connect the vast open space of the park to the upper floor. One could imagine an extension of the colonnade beyond its actual dimensions to widen the proposed divider, balancing the ellipse of "Isola Memmia".

Prussia's first public museum, originally called the Königliches Museum (Royal

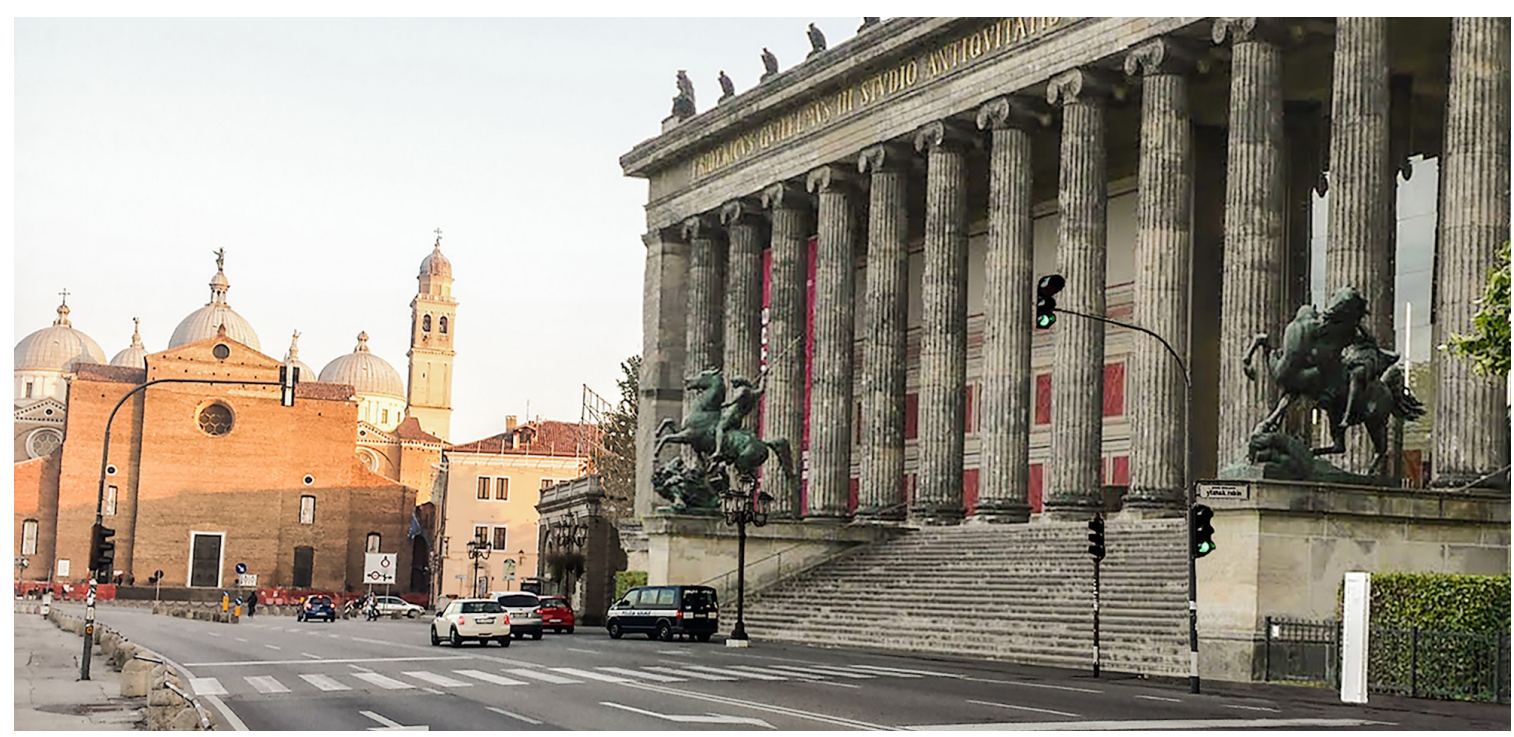

Figure 5. The Altes Museum in Berlin by Karl Friedrich Schinkel in place of the Foro Boario building. Imagine by Andrea Andolfatto and Nicolò Cappellari, students at the course of 'Architectural and Urban Composition 2', Department of Civil, Environmental and Architectural Engineering, University of Padua).

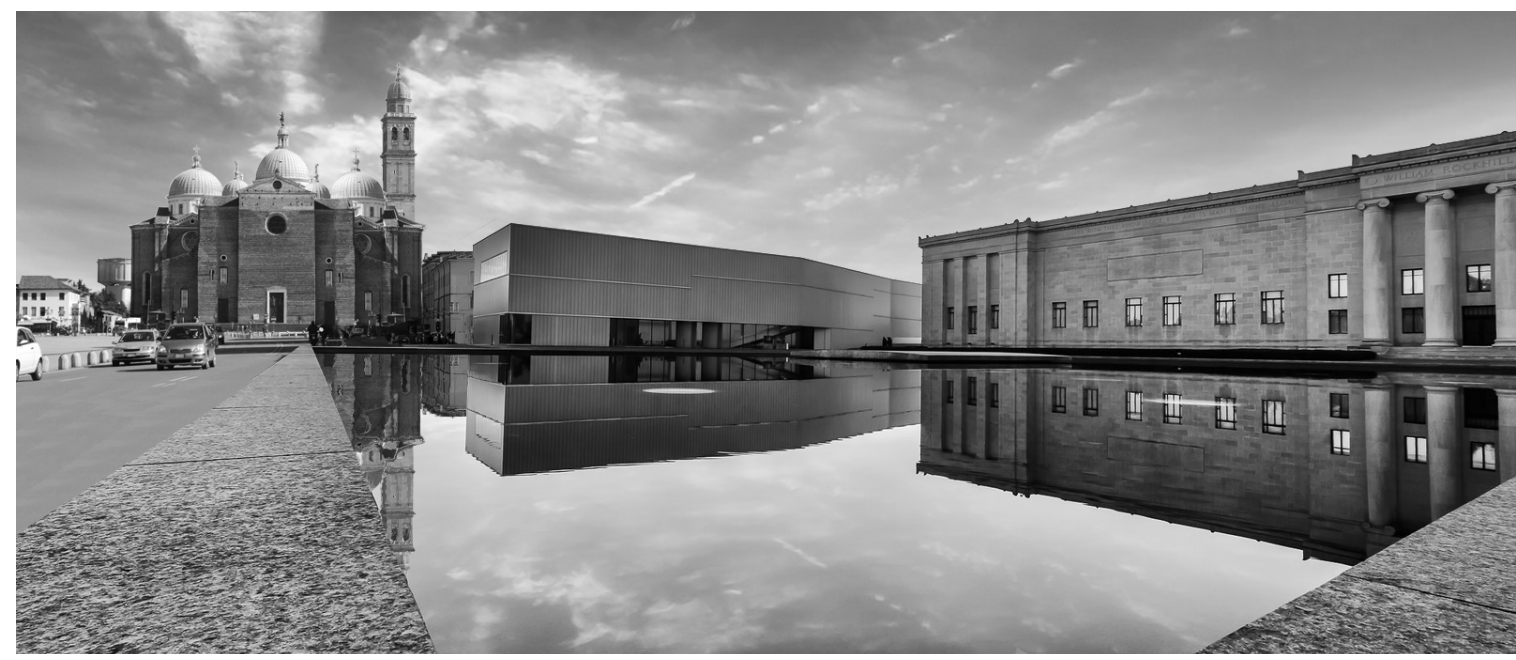

Figure 6. The Nelson-Atkins Museum of Art, Kansas City, by Thomas Wight and William Wight in place of the Foro Boario building. Imagine by Francesco Cavazzini and Marco Vettore, students at the course of 'Architectural and Urban Composition 2', Department of Civil, Environmental and Architectural Engineering University of Padua). 
Museum), was designed to house the art collections of the royal family. The location of the headquarters of an important cultural institution in Prato della Valle is not the only one hypothesis of this type thought for this vast space transformed by Enlightenment. A few years later, in 1824, Giuseppe Jappelli proposed a project for the east side, which involved another important building complex dedicated to culture - the city university. In the first half of the 20th century, an additional proposition, probably formulated by the architect Quirino De Giorgio, would have proclaimed the spatial inadequacy of the Foro Boario to match the powerful form of "Isola Memmia". After the creation of the entry to the livestock market, between 1937 and 1940, the design of Padua's headquarters of the National Fascist Party obscured Peretti's chaotic building complex from the views offered from the heart of "Isola Memmia".

The second hypothesis closes the elliptical square of Prato della Valle to the south by using the architecture of the Nelson-Atkins Museum of Art in Kansas City designed by Thomas and William Wight and built between 1930 and 1933 (Figure 6). The museum was extended with a new building by architect Steven Hall who won the tender in 1999 but it is the stone background of Wight and Wight that particularly fits the architecture desired in the exercise presented in this paper. The dynamic tension produced by the elliptical shape of the island breaks against the wall of the museum, as it happened with the wall of the Santa Maria della Misericordia convent in the proposal of Memmo and Cerato. The compactness of Wight and Wight's neoclassical façade strengthens Cerato's design conferring unity to the open space of the elliptical square by providing the certainty of well-defined boundaries on its edges.

The insertion of Thomas and William Wight's architecture also allows for an evaluation of the presence of water, which we know was once not limited to the canal around the island, but existed as an open-air stretch of the Alicorno canal in the south-eastern part of the Prato della Valle.

\section{Conclusions}

The juxtaposition of well-known architectures to provide form to new spatial connections in the environment verifies new opportunities to compose buildings and monuments that modify the space. The inventions resulting from the union of individual architectures into unitary visions that do not organically belong together is a particular iconography in which buildings abandon the passive and ornamental function thanks to which we have got to know them and reacquire an actively elevated role in the project.

The effectiveness of this method is reflected in the actual experiences of many photographers and digital designers who have been studying the theme of context by varying the elements it contains, using features that are or were found in other places or in other times. Anton Rapponen, Chris Helgren, Alexey Kondakov, Julien de Casablanca, Julia Fullerton-Batten and Alberto Alicata are just a few of the many artists that can be cited, united by their invention of context through the combination of real and imagined elements.

The focus on the southern side of the Prato della Valle in Padua also offered an opportunity to verify a possible reading of the composition of the architecture as a result of a way of thinking based on form rather than function, an aesthetic development that recognises form as a repository for the values of the community in the representation of urban spaces.

\section{References}

Arbour \& Associés (2001) Faubourg Québec, paramètres de développement urbain (Société de développement de Montréal, Montréal).

Bedin, N. (2004) 'Ex Foro Boario, 1913-14' in Cisotto Nalon M. (ed.) Padova tra '800 e ' 900 (Comune di Padova, Padova) 34.

Fontana, R. (2000) 'Ex Foro Boario', in Guide di architettura. Padova (Umberto Allemandi \& C., Turin) 199.

Radicchio, V. (1986) Descrizione della general idea, ed in gran parte effettuata dall'eccellentissimo signore Andrea Memmo sul materiale che denominavansi della Valle (Roma). 
Rossi, A. (1975) Scritti scelti sull'architettura e la città 1956-1972 (Clup, Milan).

Semerani, L. (1982) 'Attualità di Schinkel', in 1781-1841 Schinkel l'architetto del principe (Albrizzi Editore e Cluva Libreria Editrice, Venice) 9-23.

Toffanin, G. (1988) Cento chiese padovane scomparse (Editoriale Programma, Padua) 137-138.

Universo, M. (1986) 'Il Prato della Valle nell'800 e nel '900', in Puppi, L. (ed.) Prato della Valle. Due millenni di storia di un'avventura urbana (Offset Invicta, Limena/Padova) 234. 